\title{
ONE-YEAR CLINICAL INVESTIGATION OF THE EFFECT OF INCLUSION OF THREE NANOPARTICLES IN THE HEAT-CURED ACRYLIC RESIN DENTURE BASE ON THE ADHESION WITH THE SILICONE SOFT LINER
}

\author{
Hesham Samy Borg*
}

\begin{abstract}
Purpose: To evaluate the effect of incorporating three nanoparticles (Titanium oxide, silicon oxide, and alumina) with $1 \%$ and $5 \%$ concentration on the bond strength to denture base for one year of clinical service.

Methods: Fifty-six completely edentulous patients were selected and divided into seven groups according to the nanoparticle material and concentration $(n=8)$. Upper and lower complete dentures were fabricated for each patient. The adhesion of soft liner was done using a five scale questionnaire at insertion (baseline) 4, 8 , and 12 months of denture insertion. The data were analyzed by Friedman test with post-hoc Dunn test.
\end{abstract}

Results: At 4 and 8 months, all the nanoparticles groups showed a non-statistically significant difference from the baseline. At 12 months, all groups with 5\% nanoparticle concentration showed a statistically significant decrease in the soft liner adhesion. There were no significant differences between all nanoparticles groups during all follow up intervals

Conclusion: The addition of nanoparticles to the denture base effectively improved the bond between the soft-liner and the denture base, especially for $1 \%$ concentration.

KEYWORD: Acrylic resin, Adhesion, Denture, Nanoparticles, Silicone, Soft-liner

\section{INTRODUCTION}

Acrylic resin material was developed in laboratories in 1928 and introduced to the market by Rohm and Haas Company in 1933 with a Plexiglas trademark. In 1937, Dr. Walter Wright introduced polymethyl methacrylate (PMMA) as a denture base material. Around $95 \%$ of all dentures were made of acrylic in $1946^{(1)}$. It has been used widely as denture bases due to its ease of manufacturing, low cost, color matching, and lightweight. It is also used for

* Lecturer of Prosthodontics, Department of Prosthodontics, Faculty of Dentistry, Al-Salam University, Gharbia, Egypt 
many appliances such as splints, stents, and night guards ${ }^{(2)}$. Despite the popularity of acrylic resin, it is still inadequate to fulfill the ideal mechanical requirements. Clinicians also experience a material fracture due to low impact resistance, flexural stress, or fatigue stress. Acrylic resin has a low impact resistance that usually results in denture fractures ${ }^{(3)}$.

In dentistry, soft liner products have been developed as a solution to many problems. These materials will ensure an even distribution of the functional load in the denture-bearing region and avoid load stress concentration. They also improve denture retention as bone resorption occurs ${ }^{(4)}$. It has been stated that soft liner dentures are more comfortable to use compared to rigid acrylic dentures. The use of these dentures is associated with substantial improvements in articulation, chewing performance, denture retention and stability, a decrease in the perception of pain and oral ulcers under dentures, and an improvement in denture satisfaction and duration use ${ }^{(5)}$. Due to their elastic properties, these liners transmit functional and para-functional stresses and act as shock absorbers. They are used as a cushion in patients who cannot withstand denture stress due to sharp, thin, extremely resorbed ridges or bony undercuts, bruxism, and xerostomia. In edentulous arches opposed to natural dentures, and cases with congenital oral defects requiring obturation. In cases where the lower alveolar nerve is visible and in implant overdenture. Soft liners are either based on acrylic resin or silicone. Autopolymerized or heat-polymerized forms are available in both categories ${ }^{(6,7)}$.

The absence of adequate bonding to denture base materials will override the desired soft liner properties ${ }^{(8)}$. Bond failure is a problem that makes the liner surface vulnerable to fungal and bacterial growth. As oral bacteria and fungi penetration of denture soft liner material can lead to plaque, calculus formation, oral tissue infections, material deterioration, and subsequent failure ${ }^{(9)}$. The tensile bond strength of soft acrylic liners is greater than that of silicone-based materials ${ }^{(10)}$. Sandblasting, silica coating, and silane surface treatment of denture base resin did not improve the silicone base soft liner bond strength to the acrylic resin denture ${ }^{(11)}$. Seven of the eight papers concluded in a systematic review that airborne particle abrasion caused degradation of bonding between the liner and the denture base resin ${ }^{(12)}$.

The nanomaterial is classified as a natural or produced material containing particles in a nonagglomerated state, and where $50 \%$ or more of the particles have one or more external dimensions in the range of $1-100 \mathrm{~nm}^{`}{ }^{(13)}$. Numerous studies have been conducted to determine nanomaterials' effect on acrylic resin base resin's mechanical properties. A study found that acrylic resin reinforced with $1 \%$ titanium oxide showed a significant improvement in the tensile and impact strength with no harmful effects on other properties ${ }^{(14)}$. Incorporation of $0.4 \%$ titanium oxide nanoparticles into the acrylic resin polymer matrix has been shown to have an antibacterial on the Candida species. The nanocomposite was successfully made by the stereolithographic technique ${ }^{(15)}$. Alumina nanoparticles' addition to acrylic resin enhances its thermal stability and properties (decreased thermal expansion coefficient and contraction) and acrylic resin's flexural strength. It also decreases water sorption and solubility. Placing silicon carbide filler powders in the palatal area of dentures may increase acrylic resins' thermal conductivity without decreasing the strength or increasing the denture weight. ${ }^{(16)}$. Improvement of both the impact and transverse resistance of acrylic resin was achieved by incorporating silica nanoparticles with low concentrations. Increased content has resulted in nanoparticle agglomeration and cracks propagation, decreasing both hardness and fracture strength ${ }^{(17)}$. 


\section{AIM OF THE STUDY}

The purpose of this study was to determine the impact of the addition of silica, alumina, titanium nanoparticles ( $1 \%$ and $5 \%$ concentrations) in the heat-cured acrylic resin denture on the bond strength with the silicone's soft liner after one year of clinical use.

\section{MATERIALS AND METHODS}

\section{Patients grouping}

Fifty-six patients were chosen from the Output Patient Clinic, Removable Prosthodontics Department, Faculty of Dentistry, 6 October University, Giza, Egypt. Patients were randomly classified into seven groups according to the form and concentration of nanoparticles within the denture base, as shown in table (1).

TABLE (1) The list of nanoparticles used in this study.

\begin{tabular}{|l|l|}
\hline Group I & Denture had no nanoparticle (Control group) \\
\hline Group II & $\begin{array}{l}\text { Denture had a } 1 \% \text { concentration of titanium } \\
\text { oxide nanoparticles. }\end{array}$ \\
\hline Group III & $\begin{array}{l}\text { Denture had a 5\% concentration of titanium } \\
\text { oxide nanoparticles. }\end{array}$ \\
\hline Group IV & $\begin{array}{l}\text { Denture had a } 1 \% \text { concentration of aluminum } \\
\text { oxide nanoparticles. }\end{array}$ \\
\hline Group V & $\begin{array}{l}\text { Denture had a 5\% concentration of aluminum } \\
\text { oxide nanoparticles. }\end{array}$ \\
\hline Group VI & $\begin{array}{l}\text { Denture had a 1\% concentration of silicon } \\
\text { oxide (silica) nanoparticles. }\end{array}$ \\
\hline Group VII & $\begin{array}{l}\text { Denture had a 5\% concentration of silicon } \\
\text { oxide (silica) nanoparticles. }\end{array}$ \\
\hline
\end{tabular}

\section{Nanoparticle preparation}

The nanoparticles were prepared in a private laboratory (Nanogate Laboratory, Cairo, Egypt). The average size of the nanoparticles was $<20$ $\mathrm{nm}$ with a spherical shape. The structure of the nanoparticle was confirmed using a high-resolution transmission electron microscope (JEM-2100, Jeol, Akishima, Japan) and X-ray diffraction analysis using a powder diffractometer system (X'pertProPanalytical, Malvern, United Kingdom) as shown in figure (1). The nanoparticles were added to the monomer of the acrylic resin by volume concentration $(\mathrm{v} / \mathrm{v} \%)$.

\section{Fabrication of denture base with soft liner}

A silicone putty spacer (Zetaplus, Zhermzck, Rome, Italy) with $2 \mathrm{~mm}$ thickness was adapted over the cast before packing the acrylic resin in the mold. A dough mix of heat-cured acrylic resin was packed over it (Vertex TM Regular, Vertex, Soesterberg, Holland), then the flask was closed, and any excess acrylic was removed. The curing cycle was $75^{\circ} \mathrm{C}$ for 1.5 hours, then $100^{\circ} \mathrm{C}$ for an additional one hour. The cameo dentures were finished and polished. An adhesive (Mollosil Adhesive, DETAX GmbH, Ettlingen, Germany) was painted on the denture's intaglio surface and left for 1 minute to dry. Equal proportions of silicone soft liner $\left(\right.$ Mollosil $^{\circledR}$, DETAX GmbH, Ettlingen, Germany) are mixed by gun and applied on the denture's intaglio surface. The dentures were seated in the patient's mouth, and the patients were asked to close their teeth in occlusion for 5 minutes until the soft liner was set while maintaining functional movement with their lips and tongue. The excess acrylic resin was removed using no 15 -scalpel blade and smoothed with polishing stones at $15000 \mathrm{rpm}$. An equal mix of gloss varnish base and catalyst (Lustrol ${ }^{\circledR}$, DETAX $\mathrm{GmbH}$, Ettlingen, Germany) was mixed and applied over the soft liner and left to dry for 5 minutes. The patients were recalled after one week for any necessary adjustment of the denture.

The bond strength was measured according to Mutulay et al. ${ }^{(18)}$. A questionnaire was given for each patient regarding their experience of the soft liner's peeling from the denture base. The score of the questionnaire was five, according to the table (2). The patients had two questionnaires, one for each denture, and the average score for both upper and lower denture was calculated. The evaluation was done at insertion (baseline) and continue at four months, eight months, and 12 months. 


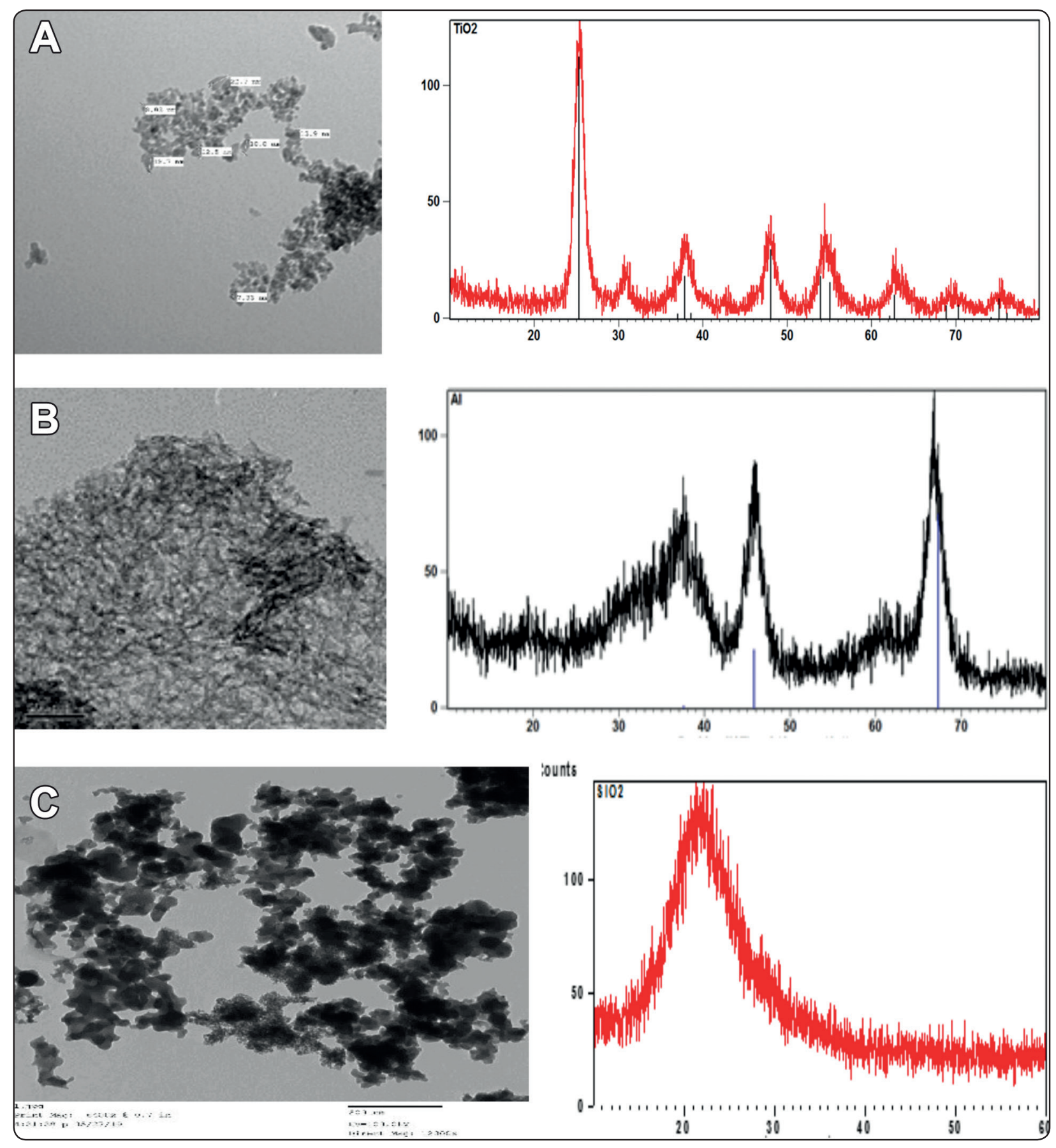

Fig. (1) Left: Scanning electron microscope photos, Right: XRD analysis of the nanoparticles A: Titanium oxide nanoparticles, (B) : Aluminum oxide nanoparticles, (C): Silica nanoparticles Measurement of the soft-liner adhesion to the denture base 
TABLE (2) Scoring of the adhesion of the soft liner to the denture base.

\begin{tabular}{|l|l|l|}
\hline Score & Value & Criteria \\
\hline 0 & Very poor & All of the soft liners have been peel off from the denture. \\
\hline 1 & Poor & Large areas of the soft liner have been peel off from both sides of the denture \\
\hline 2 & Fair & Large areas of the soft liner have been peel off from one side of the denture. \\
\hline 3 & Good & Small areas of the soft liner have been peel off from both sides of the denture. \\
\hline 4 & Very Good & Small areas of the soft liner have been peel off from one side of the denture. \\
\hline 5 & Excellent & None of the soft liner peeled off from both dentures. \\
\hline
\end{tabular}

\section{Statistical analysis}

Data were analyzed using a commercially SPSS $\odot$ program (Chicago, IL, USA version 20 for windows). Kolmogorov Smirnov test showed a non-parametric distribution of data. An analysis of the ordinal data was done using the Friedman test with a post-hoc Dunn test with a significance level $(\mathrm{p}<0.05)$.

\section{RESULTS}

The scores of soft liner adhesion to the denture base are shown in table (3) and figure (2). Data show a progressive decrease in the soft liner adhesion in all groups over time. However, the results of all groups fall between fair and very good scores. Comparison with the baseline by the Friedman test at 4 and 8 months showed a significant reduction in the adhesion scores in the control group only $(\mathrm{p}<0.05)$.

TABLE (3) Values of the soft liner bond to the denture base

\begin{tabular}{|c|c|c|c|c|c|c|c|}
\hline \multirow{2}{*}{ Group } & \multirow{2}{*}{ Time* } & \multirow{2}{*}{ Median } & \multirow{2}{*}{ Min } & \multirow{2}{*}{ Max } & \multirow{2}{*}{$\begin{array}{c}\text { Interquartile } \\
\text { range }\end{array}$} & \multicolumn{2}{|c|}{ 95\% Confidence Interval for Mean } \\
\hline & & & & & & Upper bond & Lower bond \\
\hline \multirow{3}{*}{$\begin{array}{c}\text { Group } \\
\text { I }\end{array}$} & 4 Months & 4 & 2 & 5 & 1 & 4.2032 & 2.9968 \\
\hline & 8 Months & 3 & 2 & 4 & 2 & 3.5841 & 2.4159 \\
\hline & 12 Months & 2.5 & 0 & 4 & 3 & 3.3691 & 1.2309 \\
\hline \multirow{3}{*}{$\begin{array}{c}\text { Group } \\
\text { II }\end{array}$} & 4 Months & 4 & 3 & 5 & 2 & 4.6744 & 3.3256 \\
\hline & 8 Months & 3 & 3 & 4 & 0.25 & 3.5016 & 2.8984 \\
\hline & 12 Months & 3 & 1 & 4 & 2.25 & 3.3431 & 1.6569 \\
\hline \multirow{3}{*}{ Group III } & 4 Months & 4 & 3 & 5 & 1.25 & 4.3643 & 3.2357 \\
\hline & 8 Months & 3.5 & 2 & 5 & 2.25 & 4.2397 & 2.5603 \\
\hline & 12 Months & 2 & 0 & 5 & 3.25 & 3.7275 & 1.2725 \\
\hline \multirow{3}{*}{ Group IV } & 4 Months & 4 & 3 & 5 & 1 & 4.6524 & 3.7476 \\
\hline & 8 Months & 4 & 1 & 5 & 1.25 & 4.5295 & 2.8705 \\
\hline & 12 Months & 3 & 1 & 5 & 2.5 & 4.0664 & 1.9336 \\
\hline \multirow{3}{*}{$\begin{array}{c}\text { Group } \\
\mathrm{V}\end{array}$} & 4 Months & 4 & 3 & 5 & 1.25 & 4.4278 & 3.3722 \\
\hline & 8 Months & 4 & 1 & 4 & 1 & 4.0911 & 2.7089 \\
\hline & 12 Months & 3 & 0 & 4 & 2.25 & 3.5657 & 1.6343 \\
\hline \multirow{3}{*}{ Group VI } & 4 Months & 4 & 4 & 5 & 1 & 4.6456 & 3.9544 \\
\hline & 8 Months & 4 & 2 & 5 & 2.25 & 4.7564 & 3.0436 \\
\hline & 12 Months & 3.5 & 1 & 5 & 2.5 & 4.1901 & 2.0099 \\
\hline \multirow{3}{*}{$\begin{array}{l}\text { Group } \\
\text { VII }\end{array}$} & 4 Months & 4 & 2 & 5 & 1.25 & 4.8114 & 3.3886 \\
\hline & 8 Months & 4 & 1 & 5 & 3 & 4.6770 & 2.5230 \\
\hline & 12 Months & 2.5 & 1 & 5 & 3.25 & 3.9584 & 1.6416 \\
\hline
\end{tabular}




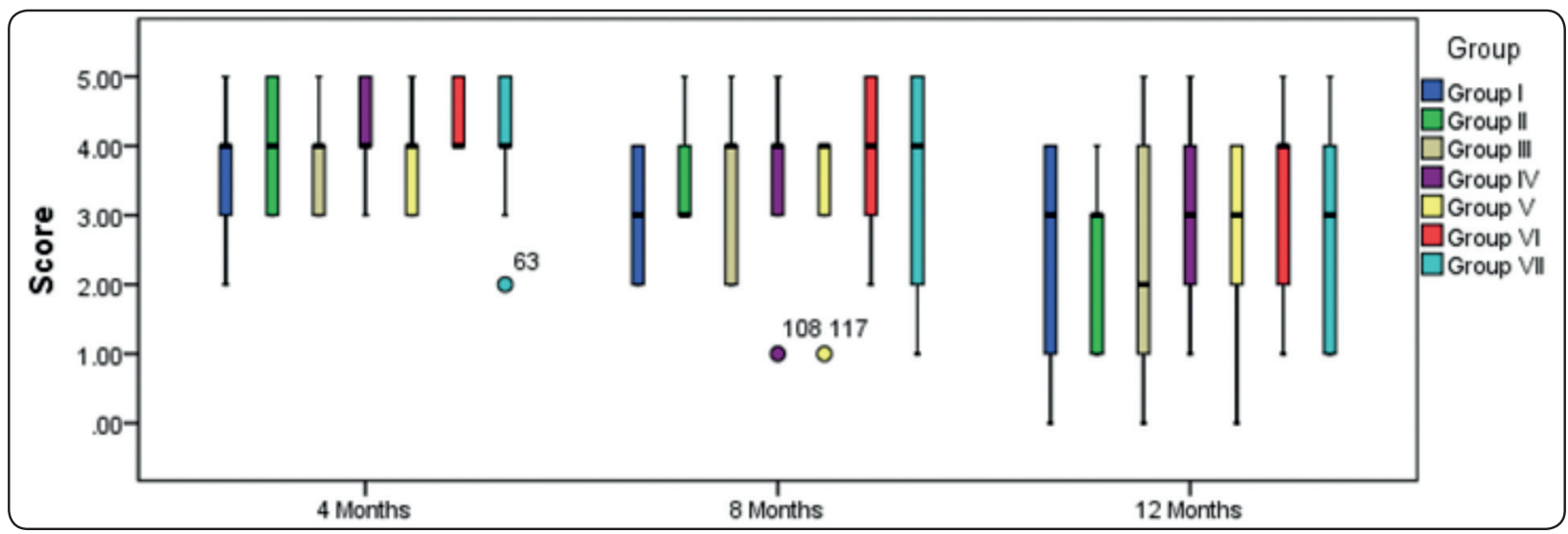

Fig. (2) Box and whisker plot of soft liner adhesion to denture base for different groups during follow-up intervals. The score at baseline were 5 for all groups

All the other groups containing nanoparticles did not significantly differ from the control group $(\mathrm{p}<0.05)$, which means that the nanoparticles effectively resist adhesion failure. At 12 months, all groups with 5\% nanoparticle concentration (Group III, V, and VII) and the control group showed a significant reduction in the adhesion from the baseline time. In between groups comparison by the Friedman test with posthoc Dunn test, the results showed a statistically non-significant difference in the soft liner adhesion between all groups during all follow-up intervals $(p<0.05)$. The in between-group comparison and comparison between groups with the baseline using the Friedman test are shown in table (4).

TABLE (4): Multiple comparisons in between groups as well as the baseline by Friedman test with post-hoc Dunn test

\begin{tabular}{|c|c|c|c|c|c|}
\hline Time & Variables & $\mathrm{F}_{\mathrm{r}}$ & $\mathrm{p}$-value & Significance & Post Hoc Dunn test (p-value) \\
\hline \multirow{2}{*}{4 Months } & Between groups & 13.233 & 0.152 & \multicolumn{2}{|r|}{ Non-Significant } \\
\hline & With baseline & 25.324 & $0.005^{*}$ & Significant & Control- Baseline $(\mathrm{p}=0.28 *)$ \\
\hline \multirow{2}{*}{8 Months } & Between groups & 14.866 & 0.95 & \multicolumn{2}{|r|}{ Non-Significant } \\
\hline & With baseline & 30.00 & $0.001 *$ & Significant & Control- Baseline $(\mathrm{p}=0.02 *)$ \\
\hline \multirow[b]{2}{*}{12 Months } & Between groups & 14.296 & 0.112 & \multicolumn{2}{|r|}{ Non-Significant } \\
\hline & With baseline & 31.655 & $0.00 *$ & Significant & $\begin{array}{l}\text { Control- Baseline }\left(\mathrm{p}=0.004^{*}\right) \\
\text { Group III-Baseline }\left(\mathrm{p}=0.1^{*}\right) \\
\text { Group V-Baseline }\left(\mathrm{p}=0.17^{*}\right) \\
\text { Group VII-Baseline }\left(\mathrm{p}=0.36^{*}\right)\end{array}$ \\
\hline
\end{tabular}

Fr: Friedman test, multiple comparisons were made using the Post-hoc Test (Dunn's)

p: p-value for comparing between the different periods in each group

*: Statistically significant at $p \leq 0.05$ 


\section{DISCUSSION}

Soft liners are a useful adjunct therapy for patients who cannot withstand a hard denture base to help patients adapt to their new dentures. A new study suggested that some $75 \%$ of patients needed to reline their implant-supported overdentures after an average of 7.8 months, and the soft liners were mostly favored as an alternative to traditional hard-relining products ${ }^{(19)}$. Silicone liners are stable in color and more resilient than acrylic liners. The polymer is an elastomer with no additional plasticizer and is thus more durable over time ${ }^{(20)}$.

There have been several issues involved with the clinical use of resilient liner material. These include staining, color change, porous surface structure, deterioration, and reduced resistance over time. As well as debonding between the denture and the resilient liner, the porous surface texture facilitates the aggregation of food debris and encourages bacterial development, which can irritate the denture bearing area and create an environment for microbial colonization ${ }^{(21)}$.

The adhesion of chairside silicone soft liners to denture base polymer has been confirmed weak by many authors ${ }^{(22-24)}$. Acrylic resin liners showed better adhesion to the denture base because the bonding between the two materials is better when they have similar chemical structures ${ }^{(25)}$. Chemical cured silicone soft liner failures may be completely adhesive or an adhesive and cohesive mix ${ }^{(26)}$. A qualitative evaluation of the failure mode using scanning electron microscopy revealed that the acrylic soft-liner showed a mainly adhesive failure pattern on the liner-acrylic resin interface. In the meantime, the silicone-based soft liner demonstrated mixed adhesive and coherent failure ${ }^{(27)}$. Improving bond by conventional methods such as surface treatment is affected by humidity, contamination, and denture base polymer's surface structure. The result is a negative effect on bond strength ${ }^{(28)}$.

A minimum of $2 \mathrm{~mm}$ of the liner and $3 \mathrm{~mm}$ of hard acrylic resin denture base are recommended for dentures with a resilient liner. A study found that $\%$ of 37 mandibular dentures with a resilient liner fractured in 3 years, and all fractures occurred because the acrylic resin was not thick enough ${ }^{(29)}$. The method of using silicone putty spacer was proposed by Kutay et al ${ }^{(30)}$.

Nanotechnology has recently entered the dental industry and has introduced many research projects to explore future uses and expected dentistry benefits. Literature shows that new mechanical and physical properties are created by nanoscale reinforcement agents, forming a new class of nanocomposites. The new composite material properties depend on the nature, size, and morphology of the added nanoparticles. ${ }^{(31)}$. Nanoparticles were added to the denture base because it had lower values of nanoparticle release. A comparative study of nanoparticle release from denture base, liner, and adhesive showed that the release was higher in the denture adhesive followed by liner and denture base ${ }^{(32)}$. Increase release of the nanoparticle may cause systemic toxicity, especially to the CNS ${ }^{(33)}$.

Due to the strong inter-atomic ionic bonding associated with the most stable alpha hexagonal phase with high dialectical properties, the increase in the bonding strength of soft lining material to alumina nanoparticles can result in the formation of cross bonding and high bonding forces between nanofillers and resin material. The result is the polymer's mobility limitation and a dense composite polymer matrix formation ${ }^{(34)}$. Silica nanoparticles also create a dense composite matrix that increases the bonding strength of the soft-liner material to the denture base by preventing water from entering the denture and preventing the plasticizer from leaching from the soft liner. ${ }^{(35)}$. The same mechanism occurs with titanium-oxide nanoparticles ${ }^{(36)}$. Indeed, titanium oxide nanoparticles have high surface energy to form strong bonds with acrylic resin polymer matrix interfaces, resulting in increased van der Waals strengths and increased polymer chain crosslinking ${ }^{(37)}$. 
On the other hand, the degree of conversion is influenced by an increasing amount of nanoparticles. The residual monomer is trapped in the polymer network and acts as a plasticizer ${ }^{(38)}$. Residual monomer and water sorption in acrylic resin denture base are closely associated. ${ }^{(39)}$. Water penetrates the soft liner and denture resin base interface and causes swelling and concentration of the applied stresses. So, the soft liner's viscoelastic properties are changed. Instead of a cushioning effect, it transfers external loads directly to the acrylic interface and reduces interface resistance to degradation and fracture. ${ }^{(40)}$. This mechanism may explain the lower values of adhesion at 5\% nanoparticles after 12 months of clinical service

Although the control group results after 4, 8 , and 12 months were significant from the baseline, the recorded score after 12 months still fair for clinical use. The results agree with a 3-year retrospective study by Wright et al., where only three dentures of 39 patients showed an edge failure of adhesion ${ }^{(41)}$. Mutually et al. ${ }^{(18)}$ showed an average score of 3.9, which was greater than the current. But this increase in his due to the use of heat-cured soft liner, which showed more adhesion to the acrylic denture than the chemical cured one ${ }^{(42)}$

\section{CONCLUSION}

Addition of nanoparticles to the denture base effectively improved the bond between the soft-liner and the denture base, especially for concentrations below $5 \%$.

\section{REFERENCES}

1. Murrary M. The evolution of complete denture. Aust Dent J. 1993;38:216-19.

2. Vojdani M, Bagheri R, Khaledi A. Effects of aluminum oxide addition on the flexural strength, surface hardness, and roughness of heat-polymerized acrylic resin. J Dent Sci. 2012;7(3):238-44.
3. Yilmaz C, Korkmaz T. The reinforcement effect of nano and microfillers on fracture toughness of two provisional resin materials. Mater Des. 2007;28(7):2063-70.

4. Arafa k. Effect of soft liner material on retention of complete denture, an in vitro study. Life Sci J. 2012;9:1269-98.

5. Kimoto S, Kimoto K, Gunji A, Kawai Y, Murakami H, Tanaka K, et al. Clinical effects of acrylic resilient denture liners applied to mandibular complete dentures on the alveolar ridge. J Oral Rehabil. 2007;34(11):862-9.

6. Tata S, Nandeeshwar D. A clinical study to evaluate and compare the masticatory performance in complete denture wearers with and without soft liners. J contemp Dent Pract. 2012;13:787-92.

7. Saravanan M. Viscoelastic properties and antimicrobial effects of soft liners with silver zeolite in complete dental prosthesis wearers: an in vivo study. Int J Prosthodont. 2015;28:265-9.

8. Sinobad D, Murphy W, Huggett R, Brooks S. Bond strength and rupture properties of some soft denture liners. J Oral Rehabil. 1992;19(2):151-60.

9. Chladek G, Kasperski J, Barszczewska I, Zmudzki J. Sorption, solubility, bond strength and hardness of denture soft lining incorporated with silver nanoparticles. Int J Mol Sci. 2012;14(1):563-74.

10. Mese A, Guzel K, Uysal E. Effect of storage duration on tensile bond strength of acrylic or silicone-based soft denture liners to a processed denture base polymer. Acta Odontol Scand. 2005;63(1):31-5.

11. Atsu S, Keskin Y.Effect of silica coating and silane surface treatment on the bond strength of soft denture liner to denture base material. J Appl Oral Sci. 2013;21(4):300-6.

12. Muddugangadhar B, Mawani D, Das A, Mukhopadhyay A. Bond strength of soft liners to denture base resins and the influence of different surface treatments and thermocycling: A systematic review. J Prosthet Dent. 2019.

13. Bondarenko O, Juganson $\mathrm{K}$, Ivask A, Kasemets $\mathrm{K}$, Mortimer M, Kahru A. Toxicity of Ag, Cuo, and Zno nanoparticles to selected environmentally relevant test organisms and mammalian cells in vitro : a critical review. Arch Toxico. 2013;87:1181-200.

14. Ghahremani L, Shirkavand S, Akbari F, Sabzikari N. Tensile strength and impact strength of color modified acrylic resin reinforced with titanium dioxide nanoparticles. J Clin Exp Dent. 2017;9(5):e661-e5. 
15. Totu E, Nechifor A, Nechifor G, Aboul-Enein H, Cristache C. Poly(methyl methacrylate) with $\mathrm{TiO} 2$ nanoparticles inclusion for stereolitographic complete denture manufacturing - the fututre in dental care for elderly edentulous patients? J Dent. 2017;59:68-77.

16. Kul E, Aladag L, Yesildal R. Evaluation of thermal conductivity and flexural strength properties of poly(methyl methacrylate) denture base material reinforced with different fillers. J Prosthet Dent. 2016;116(5):803-10.

17. Balos S, Pilic B, Markovic D, Pavlicevic J, Luzanin O. Poly(methyl-methacrylate) nanocomposites with low silica addition. J Prosthet Dent. 2014;111(4):327-34.

18. Mutluay M, Oguz S, Floystrand F, Saxegaard E, Dogan A, Bek B, et al. A prospective study on the clinical performance of polysiloxane soft liners: one-year results. Dent Mater J. 2008;27(3):440-7.

19. Attard N, David L, Zarb G. Immediate loading of implants with mandibular overdentures: one-year clinical results of a prospective study. Int J Prosthodont. 2005;18(6):463-70.

20. Kulak-Ozkan Y, Sertgoz A, Gedik H. Effect of thermocycling on tensile bond strength of six silicone-based, resilient denture liners. J Prosthet Dent. 2003; 89(3):303-10.

21. Radford D, Challacombe S, Walter J. Denture plaque and adherence of Candida albicans to denture-base materials in vivo and in vitro. Crit Rev Oral Biol Med. 1999;10(1): 99-116.

22. Braden M, Wright PS, Parker S. Soft lining materials--a review. Eur J Prosthodont Restor Dent. 1995;3(4):163-74.

23. Kutay O, Bilgin T, Sakar O, Beyli M. Tensile bond strength of a soft lining with acrylic denture base resins. Eur J Prosthodont Restor Dent. 1994;2(3):123-6.

24. McCabe JF, Carrick TE, Kamohara H. Adhesive bond strength and compliance for denture soft lining materials. Biomaterials. 2002;23(5):1347-52.

25. Hussein B, Ismail I, Khalaf H. Effect of some disinfectant solutions on the hardness property of selected soft denture liners after certain immersion periods. J Fac Med Baghdad. 2009;51:259-64.

26. Muralidhar G, Satish C, Shetty S. Integrity of the interface between denture base and soft liner: a scanning electron microscopic study. J Ind Prosth Soc. 2012;12(2):72-7.

27. Rajaganesh N, Sabarinathan S, Azhagarasan N, Shankar C, Krishnakumar J, Swathi S. Comparative evaluation of shear bond strength of two different chairside soft liners to heat processed acrylic denture base resin: An in vitro study. J Pharm Bioall Sci. 2016;8(Suppl 1):S154-S9.

28. Mutluay M, Ruyter I. Evaluation of bond strength of soft relining materials to denture base polymers. Dent Mater. 2007;23(11):1373-81.

29. Makila E, Honka O. Clinical study of a heat-cured silicone soft lining material. Journal of oral rehabilitation. 1979;6(2):199-204.

30. Kutay O. A silicone rubber spacer used to determine the optimum thickness for hard and resilient materials in complete dentures. The Journal of prosthetic dentistry. 1993;69(3):329-32.

31. Gad M, Abualsaud R. Behavior of pmma denture base materials containing titanium dioxide nanoparticles: A literature review. Int J Biomater. 2019;2019:6190610.

32. Shoeib A, Shaker M, Abdeen R, El-Segai A. Evaluation of silver and copper oxide NANOPARTICLES release from different prosthetic materials incorporated with nanoparticles. Egypt Dent J. 2019;65:2849-55.

33. Feng X, Chen A, Zhang Y, Wang J, Shao L, Wei L. Central nervous system toxicity of metallic nanoparticles. Int $\mathrm{J}$ Nanomedicine. 2015;10:4321-40.

34. Hassan A, Vuksanovic M, Kojovic A, Stojanović D, K $\mathrm{O}$, Jancic $\mathrm{R}$, et al. The effect of alumina nanofillers size and shape on mechanical behavior of PMMA matrix composite. J Serb Chem Soc. 2014;79:1295.

35. into J, Mesquita M, Henriques G, de Arruda Nobilo M. Effect of thermocycling on bond strength and elasticity of 4 long-term soft denture liners. J Prosthet Dent. 2002;88(5):516-21.

36. Alwan SA, Al-Ameer SSJJobcod. The effect of the addition of silanized Nano titania fillers on some physical and mechanical properties of heat cured acrylic denture base materials. J Bagh Coll Dent. 2015;27:86-91.

37. Khalaf H, Salman T. The influence of adding of modified zro2-tio2 nanoparticles on certain physical and mechanical properties of heat polymerized acrylic resin. J Bag Coll Dent. 2015;27:33-9.

38. Shibata T, Hamada N, Kimoto K, Sawada T, Sawada $\mathrm{T}$, Kumada H, et al. Antifungal effect of acrylic resin containing apatite-coated tio photocatalyst. Dent Mater J 2007;26(3):437-44. 
39. Pfeiffer P, Rosenbauer E. Residual methyl methacrylate monomer, water sorption, and water solubility of hypoallergenic denture base materials. J Prosthet Dent. 2004;92(1):72-8.

40. Elias C, Henriques F. Effect of thermocycling on the tensile and shear bond strengths of three soft liners to a denture base resin. J Appl Oral Sci. 2007;15(1):18-23.
41. Wright PS. The success and failure of denture softlining materials in clinical use. Journal of Dentistry. 1984;12(4):319-27.

42. Madan N, Datta K. Evaluation of tensile bond strength of heat cure and autopolymerizing silicone-based resilient denture liners before and after thermocycling. Indian $\mathbf{J}$ Dent Res. 2012;23(1):64-8. 